\title{
ЩОДО МОЖЛИВОСТЕЙ ЗАКЛАДІВ ОХОРОНИ ЗДОРОВ'Я ЗАБЕЗПЕЧИТИ ЖІНОК КОМПЛЕКСНОЮ МЕДИЧНОЮ ДОПОМОГОЮ ЗА УМОВ ВПРОВАДЖЕННЯ ДРУГОГО ЕТАПУ РЕФОРМИ СИСТЕМИ ОХОРОНИ ЗДОРОВ'Я (ЗА АНАЛІЗОМ ЗАТВЕРДЖЕНИХ ПАКЕТІВ МЕДИЧНИХ ПОСЛУГ)
}

\author{
1Національна медична академія післядипломної освіти імені П. Л. Шупика, м. Київ, Україна \\ ${ }^{2}$ ДВНЗ «Ужгородський національний університет», м. Ужгород, Україна
}

\begin{abstract}
Мета: дослідити можливість закладів охорони здоров'я за умов впровадження другого етапу реформи системи охорони здоров'я забезпечити жінок комплексною медичною допомогою.

Матеріали і методи. У ході дослідження використано бібліосемантичний метод та метод структурно-логічного аналізу. Матеріалами дослідження стали пакети медичних послуг, за якими Національна служба здоров'я України в рамках Програми медичних гарантій з 1 квітня 2020 р. укладає договори з закладами охорони здоров'я спеціалізованої та високоспеціалізованої медичної допомоги, та пакети медичних послуг, які вже діють на рівні первинної медичної допомоги.

Результати. Проаналізовано 9 із 29 пакетів медичних послуг, затверджених у рамках програми державних гарантій на 2020 р. У цілому затверджені пакети медичних послуг забезпечують певний обсяг первинної, діагностичної, амбулаторної та стаціонарної акушерсько-гінекологічної допомоги. Однак частина пакетів, у тому числі із забезпечення первинної, діагностичної та пологової допомоги, має недоліки, які ускладнюють доступність допомоги, її якість та раціональність використання ресурсів.

Висновки. Аналіз затверджених пакетів медичних послуг показав, що їх запровадження не дозволяє забезпечити жінок акушерсько-гінекологічною допомогою в повному обсязі, що потребує їх корекції на 2021 р.
\end{abstract}

КЛЮчОВІ СЛОВА: система охорони здоров'я; реформування; другий етап; пакети медичних послуг; жінки; медична допомога; забезпечення.

В Україні, відповідно до Закону України «Про державні фрінансові гарантії медичного обслуговування населення» [3], проводиться поетапне рефрормування системи охорони здоров'я та впровадження пакетів медичних послуг. Одним із принципів розробки програми медичних гарантій $€$ пріоритизація медичних послуг. Міністерство охорони здоров'я України затвердило наказ від 26.07.2019 р. № 1709, який зареєстровано в Міністерстві юстиції України 23 серпня 2019 р. за № 961/33932 «Про затвердження Порядку розробки програми державних гарантій медичного обслуговування населення» [4], та пріоритетні напрями розвитку сорери охорони здоров'я на 2020-2022 рр. Ці напрями були враховані в програмі медичних гарантій. Гарантований пакет - це набір правил щодо того, які послуги гарантовані пацієнтам, якими є правила їх отримання, чи всі пацієнти мають право на їх отримання. Перший етап реформи, який впроваджено з 2018 р., передбачав впровадження пакета «Первинна медична допомога». Другий етап передбачає впровадження комплексу пакетів для спеціалізованої

(с) О. С. Щербінська, І. Я. Гуцол, 2020 та високоспеціалізованої медичної допомоги. Всього на початку другого етапу рефрорм затверджено 29 пакетів медичних послуг [1].

Важливим питанням на даному етапі проведення рефрорми охорони здоров'я є забезпечення жінок комплексом спеціалізованої медичної допомоги, якої вони потребують в зв'язку із погіршенням показників гінекологічного здоров'я [5-7].

Мета роботи: дослідити можливість закладів охорони здоров'я за умов впровадження другого етапу реформи системи охорони здоров'я забезпечити жінок комплексною медичною допомогою.

Матеріали і методи. У ході дослідження використано бібліосемантичний метод та метод структурно-логічного аналізу. Матеріалами дослідження стали пакети медичних послуг, за якими Національна служба здоров'я України в рамках Програми медичних гарантій 31 квітня 2020 р. укладає договори з закладами охорони здоров'я спеціалізованої та високоспеціалізованої медичної допомоги, та пакети медичних послуг, які вже діють на рівні первинної медичної допомоги.

Результати дослідження та їх обговорення. У ході проведеного дослідження ми вивчали 
питання включення до пакетів медичних послуг послуг, які пов'язані з плануванням сім'ї та профрілактикою небажаної вагітності, медичною допомогою при гінекологічних захворюваннях та інфекціях, що передаються статевим шляхом, раннім виявленням злоякісних новоутворень та медичної допомоги при них, медичною допомогою, яка пов'язана з вагітністю, пологами та післяпологовим періодом.

По кожному пакету медичних послуг аналізували специфрікацію надання медичних послуг та умови закупівлі медичних послуг.

Пакет медичних послуг «Первинна медична допомога».

Аналіз специфрікації надання медичних послуг за напрямом «Первинна медична допомога» показав, що окремим пунктом визначено динамічне спостереження за жінками 3 неускладненим перебігом вагітності та направлення їх (у разі потреби) до лікаря-акушера-гінеколога закладу вторинної (спеціалізованої) або третинної (високоспеціалізованої) медичної допомоги.

Інші пункти обсягів послуг (специфікація) відповідно до потреб пацієнтів є загальними.

Не визначені такі обов'язкові послуги, як профрілактичні огляди жінок на виявлення на ранніх стадіях розвитку візуальних форм злоякісних новоутворень: рак молочної залози та шийки матки, а також консультативна допомога з питань планування сім'ї та попередження небажаної вагітності.

Аналіз умов закупівлі медичних послуг за напрямом «Первинна медична допомога» показав, що визначені документом вимоги до переліку обладнання за місцем надання послуги не дають можливості забезпечити жінок гінекологічною допомогою, в тому числі проведення профрілактичних гінекологічних оглядів, та забезпечити допомогою при інорекціях, що передаються статевим шляхом. При цьому необхідно відзначити, що чинними є наказ МОЗ України від 08.04.2019 р. № 797 «Про внесення змін до Примірного табеля матеріально-технічного оснащення закладів охорони здоров'я та фрізичних осіб-підприємців, які надають первинну медичну допомогу» [2], який при розробці пакета медичних послуг за напрямом «Первинна медична допомога» не був врахований.

Пакет медичних послуг «Амбулаторна вторинна (спеціалізована) та третинна (високоспеціалізована) медична допомога дорослим та дітям, включаючи медичну реабілітацію та стоматологічну допомогу».

Аналіз специфікації надання та умов закупівлі медичних послуг за напрямом «Амбулаторна вторинна (спеціалізована) та третинна (високоспеціалізована) медична допомога дорослим та дітям, включаючи медичну реабілітацію та стоматологічну допомогу» дав змогу зробити висновок, що амбулаторна вторинна (спеціалізована) та третинна (високоспеціалізована) медична допомога жіночому населенню має бути доступною. Позитивним $€$ визначення даними документами, що підставами надання послуг $€$ самозвернення до лікаря-акушера-гінеколога, лікаря-гінеколога дитячого та підліткового віку, а не тільки їх скерування на вищий рівень медичної допомоги сімейним лікарем.

Недоліком даного документа $є$ те, що документами не визначені вимоги до обладнання до закладів охорони здоров'я, які надають спеціалізовану та високоспеціалізовану медичну допомогу.

Окремо, в межах Програми медичних гарантій, виділено пакети пріоритетних медичних послуг інструментальних досліджень для ранньої діагностики новоутворень. Цей напрям визначено пріоритетним у сорері охорони здоров'я України у 2020-2022 рр. У даному випадку пріоритетні послуги - це переважно дороговартісні обстеження, які відповідають міжнародним рекомендаціям до їх проведення. Для жіночого населення це наступні пакети медичних послуг:

- «Мамографія грудних залоз»;

- «Гістероскопія (діагностична / з ендоскопічною маніпуляцією)».

Застосування даних пакетів дозволить забезпечити своєчасну діагностику, в тому числі на ранніх стадіях розвитку злоякісних новоутворень у жінок. Недоліком даних пакетів вважаємо те, що підставами надання послуг за направленням лікаря з надання ПМД, з яким укладено декларацію про вибір лікаря, або лікуючого лікаря, є вік жінки. Для проведення мамографії грудних залоз жінка має бути віком від 40 років і старше, а для проведення гістероскопії - від 50 років і старше. 3лоякісні новоутворення у жінок відповідних локалізацій розвиваються і у молодому віці. Вважаємо, що подібні вікові обмеження встановлювати категорично не треба, а дозволити направляти на обстеження і за клінічними показаннями у більш молодому віці.

Пакет медичних послуг «Стаціонарна допомога дорослим та дітям без проведення хірургічних операцій».

Цей пакет охоплює левову частку госпіталізацій, які відбуваються в Україні. Він включає госпіталізації за досить широким переліком напрямів: профілактика, діагностика, лікування (у тому числі медикаментозне), медична реабілітація в гострий період; госпіталізації, пов'язані з патологією вагітності; огляд пацієнта, інструментальні та лабораторні дослідження, знеболювання і медикаментозна терапія.

Використання даного пакета забезпечить жінок при гінекологічних захворюваннях стаціонарною терапевтичною допомогою та наданням 
медичної допомоги вагітним з ускладненим перебігом вагітності та/або з екстрагенітальною патологією.

Пакет медичних послуг «Хірургічні операції дорослим та дітям у стаціонарних умовах».

До пакета входять хірургічні операції за досить широким переліком спеціальностей; огляд пацієнта; лабораторні та інструментальні дослідження; проведення операцій разом з анестезіологічним супроводом; знеболювання і медикаментозна терапія; медикаментозне забезпечення, реабілітація в гострий період.

Впровадження даного пакета забезпечить жінок гінекологічною хірургічною стаціонарною допомогою в рамках пакета державних гарантій безоплатної медичної допомоги.

Пакет медичних послуг «Медична допомога при пологах».

Аналіз специфікації надання та умов закупівлі медичних послуг за напрямом «Медична допомога при пологах» вказує на можливість отримати жінками безоплатно комплекс медичних послуг при пологах. При цьому в проаналізованих документах не врахована існуюча система закладів перинатальної допомоги за її рівнями. Тільки п'ятий пункт специфікації послуг вказує на те, що проведення планового кесаревого розтину проводять у закладах охорони здоров'я II та III рівнів перинатальної допомоги.

Така ситуація може призвести до зниження якості медичної допомоги вагітним при пологах із високим акушерським ризиком та до недостатньо раціонального використання ресурсів.

Окремими пакетами медичної допомоги передбачено забезпечення населення за напрямами:
- «Діагностика та хіміотерапевтичне лікування онкологічних захворювань у дорослих та дітей »;

- «Діагностика та радіологічне лікування онкологічних захворювань у дорослих та дітей».

За даними пакетами надають таку медичну допомогу, як: консультування/діагностика людей 3 підозрою на новоутворення, медикаментозне лікування (хіміотерапія, гормонотерапія, імунотерапія, таргетна терапія), проведення променевої терапії (дистанційна, контактна), лікування методами ядерної медицини та/або радіонуклідної терапії, догляд, знеболювання пацієнтів із підтвердженим діагнозом, медична реабілітація у гострому стані.

\section{Висновки}

Проаналізовано 9 із 29 пакетів медичних послуг, затверджених у рамках програми державних гарантій на 2020 р. У цілому затверджені пакети медичних послуг забезпечують певний обсяг первинної, діагностичної, амбулаторної та стаціонарної акушерсько-гінекологічної допомоги. Однак частина пакетів, у тому числі із забезпечення первинної, діагностичної та пологової допомоги, має недоліки, які ускладнюють доступність допомоги, її якість та раціональність використання ресурсів.

Аналіз затверджених пакетів медичних послуг показав, що їх запровадження не дозволяє забезпечити жінок акушерсько-гінекологічною допомогою в повному обсязі, що потребує їх корекції на 2021 р.

Перспективи подальших досліджень пов'язані з вивченням фрактичної якості та доступності акушерсько-гінекологічної допомоги за умов реформованої системи охорони здоров'я.

\section{Список літератури}

1. Пакети медичних послуг. Зміст та підхід до контрактування закладів охорони здоров'я / Національна служба здоров'я України. - К., 2020. - 59 с.

2. Про внесення змін до Примірного табеля матеріально-технічного оснащення закладів охорони здоров'я та фрізичних осіб-підприємців, які надають первинну медичну допомогу : наказ МОЗ України від 08.04.2019 р. № 797 [Електронний ресурс]. - Режим доступу : https://moz.gov.ua/uploads/2/11606-dn_20190408_797.pdf. - Назва з екрана. 3. Про державні фрінансові гарантії медичного обслуговування населення : Закон України від 19 жовтня 2017 р. № 2168-VIII [Електронний ресурс]. - Режим доступу : http://search.ligazakon.ua/l_doc2.nsf/link1/T172168.html. - Haзва з екрана.

4. Про затвердження Порядку розробки програми державних гарантій медичного обслуговування населення : наказ МОЗ України від 26 липня 2019 р. № 1709, зареєстровано в Міністерстві юстиції України 23 серпня 2019 р. за № 961/33932 [Електронний ресурс]. - Режим доступу : http://search.ligazakon.ua/l_doc2.nsf/link1/RE33932.html. Назва з екрана.

5. Рак в Україні: захворюваність, смертність, показники діяльності онкологічної служби [Електронний ресурс] / 3. П. Федоренко, Л. О. Гулак, Є. Л. Горох та ін. - 2019. - Режим доступу до ресурсу : http://www.ncru.inf.ua/publications/. 6. Слабкий Г. О. Характеристика абортів у жінок України / Г. О. Слабкий, О. С. Щербинська // Економіка і право охорони здоров'я України. - 2019. - № 1. - С. 70-74.

7. Стан здоров'я жіночого населення в Україні за 2017 рік [Електронний ресурс] / Центр медичної статистики МОЗ України. - 2018. - Режим доступу до ресурсу : http://medstat.gov.ua/ukr/MMXVII.html/. 


\section{References}

1. (2017). Zakon Ukrainy „Pro derzhavni finansovi harantii medychnoho obsluhovuvannia naselennia” 19 zhovtnia 2017 roku № 2168-VIII [Law of Ukraine "On State Financial Guarantees of Medical Care of the Population" October 19, 2017 No. 2168-VIII]. Retrieved from: http://search.ligazakon.ua/l_doc2.nsf/link1/T172168.html [in Ukrainian].

2. (2019). Nakaz MOZ Ukrainy vid 08.04.2019 № 797 "Pro vnesennia zmin do Prymirnoho tabelia materialno-tekhnichnoho osnashchennia zakladiv okhorony zdorovia ta fizychnykh osib-pidpryiemtsiv, yaki nadaiut pervynnu medychnu dopomohu" [Order of the Ministry of Health of Ukraine dated April 8, 2019 No. 797 "On Amendments to the Model Table of Material and Technical Equipment of Health Care Institutions and Individual Entrepreneurs Providing Primary Care"]. Retrieved from: https://moz.gov.ua/uploads/2/11606-dn_20190408_797.pdf [in Ukrainian].

3. (2019). Nakaz MOZ Ukrainy vid 26 Iypnia 2019 roku N 1709, zareiestrovano v Ministerstvi yustytsii Ukrainy 23 serpnia 2019 r. za N 961/33932 "Pro zatverdzhennia Poriadku rozrobky prohramy derzhavnykh harantii medychnoho obsluhovuvannia naselennia" [Order of the Ministry of Health of Ukraine dated July 26, 2019 No. 1709, registered in the Ministry of Justice of Ukraine on August 23, 2019 No. 961/33932 "On approval of the Procedure for developing a program of state guarantees of medical care"]. Retrieved from: http://search.ligazakon.ua/l_doc2.nsf/link1/RE33932.html [in Ukrainian].

4. (2020). Pakety medychnykh posluh. Zmist ta pidkhid do kontraktuvannia zakladiv okhorony zdorovia. Natsionalna sluzhba zdorovia Ukrainy [Packages of medical services. Content and approach to contracting health care facilities. National Health Service of Ukraine]. Kyiv [in Ukrainian].

5. Fedorenko, Z.P., Hulak, L.O., Horokh, Ye.L., Ryzhov, A.Yu., Sumkina, O.V., \& Kutsenko, L.B. (2019). Rak v Ukraini: zakhvoriuvanist, smertnist, pokaznyky diialnosti onkolohichnoi sluzhby [Cancer in Ukraine: morbidity, mortality, indicators of oncological service]. Retrieved from: http://www.ncru.inf.ua/publications/ [in Ukrainian].

6. (2018). Zdorovia zhinochoho naselennia v Ukraiini za 2017 rik [Health of the female population in Ukraine in 2017]. Tsentr medychnoi statystyky MOZ Ukrainy. Retrieved from: http://medstat.gov.ua/ukr/MMXVII.html/ [in Ukrainian].

7. Slabkyi, H.O., \& Shcherbynska, O.S. (2019). Kharakterystyka abortiv u zhinok Ukrainy [Characteristics of abortion in women of Ukraine]. Ekonomika i pravo okhorony zdorovia Ukrainy - Economics and Law of Health of Ukraine, 1, 70-74 [in Ukrainian].

\section{THE CAPABILITIES OF HEALTH CARE INSTITUTIONS IN THE CONDITIONS OF IMPLEMENTATION OF THE SECOND STAGE OF HEALTH CARE SYSTEM REFORM AS FOR PROVIDING WOMEN WITH COMPREHENSIVE MEDICAL CARE}

(according to the analysis of approved medical service packages)

O. S. Shcherbinska ${ }^{1}$, I. Ya. Hutsol ${ }^{2}$

${ }^{1}$ P. Shupyk National Medical Academy of Postgraduate Education, Kyiv, Ukraine

2 Uzhhorod National University, Uzhhorod, Ukraine

Purpose: to study the possibility of health care establishments in the frames of implementation of the second stage of the health care system reform as for provision of women with comprehensive medical care.

Materials and Methods. Bibliosemantic method and the method of structural-and-logical analysis were applied in the course of research. Medical service packages for which the National Health Care Service of Ukraine concludes agreements with health care establishments of specialized and highly specialized medical care from April 1, 2020 within the framework of the Medical Guarantees Program and medical service packages that are already working at the level of primary medical care were used as the materials of study.

Results. 9 of the 29 medical services packages approved within the framework of the State Guarantee Program for the year 2020 were analyzed. In general, approved health care packages provide a certain amount of primary, diagnostic, outpatient and inpatient obstetric and gynecological care. However, definite part of the packages, including the provision of primary, diagnostic and maternity care, have disadvantages that complicate the accessibility of care, its quality and sustainability of resources.

Conclusions. The analysis of approved healthcare service packages showed that their introduction does not fully provide women with obstetric and gynecological care and require correction for the year 2021.

KEYWORDS: health care system; reformation; second stage; medical service packages; women; medical care; provision.

Рукопис надійшов до редакції 15.05.2020 р.

Відомості про авторів:

щербінська Олена Станіславівна - кандидат медичних наук, асистент кафедри акушерства, гінекології та перинатології Національної медичної академії післядипломної освіти імені П. Л. Шупика; тел.: +38(044) 257-27-27.

Гуцол Іванна Ярославівна - асистент кафедри наук про здоров'я ДВНЗ «Ужгородський національний університет». 